\title{
WhatsApps Group sebagai Media Mengajar: Keterampilan Guru
}

\author{
Rasyidi \\ SD Negeri No. 121/IX Jerambah Bolong, Jambi, Indonesia \\ rasydi.sd@gmail.com
}

\begin{abstract}
Abstrak
Tujuan penelitian ini untuk meningkatkan keterampilan guru dalam melakukan pembelajaran dengan WhatsApp Group (WAG). Adapun metode penelitian ini menggunakan penelitian tindakan sekolah dengan pendekatan deskriptif. Sampel penelitian ini diberikan perlakuan dalam bentuk pelatihan, dan terdiri dari semua guru di SDN No. 121/IX Jerambah Bolong serta dilaksanakan selama kurang lebih 4 bulan dimulai 27 Juli sampai dengan 29 Oktober 2020. Pada siklus I nilai rata-rata nilai Indikator Keterampilan Guru dalam Mengajar Menggunakan Media WAG pada angka $63,64 \%$ hal ini masih jauh dari yang diharapkan dengan pencapaian $70 \%$ sehingga perlu dilakukan Siklus II, pada siklus II pencapaian keterampilan guru mengajar dengan menggunakan media WAG pada angka 86,36\% dan telah melbihi dari target yang diinginkan yaitu 70\%. Sehingga, dengan bimbingan Menggunakan Media WAG pada guru dalam rangka peningkatan keterampilan mengajar di SDN No. 121/IX Jerambah Bolong telah berhasil. Keterbaruan dalam penelitian ini adalah penggunaan media WhatsApp sebagai wadah untuk pengingkatan keteampilan guru.
\end{abstract}

Kata kunci: keterampilan guru, whatsapp, pelatihan.

Dikirim: 18 Maret 2021

Direvisi: 08 April 2021

Diterima: 19 Mei 2021

Identitas Artikel:

Rasyidi, R. (2021). Whatsapps Group sebagai Media Mengajar: Keterampilan Guru. Jurnal Ilmu Pendidikan (JIP) STKIP Kusuma Negara, 13(1), 67-75.

\section{PENDAHULUAN}

Guru merupakan sebuah profesi yang memiliki kedudukan yang strategis untuk meningkatkan kecerdasan bangsa. Hal ini sesuai dari amanat undang-undang dasar Negara wajib menuntaskan kebodohan. Sehingga upaya pensejahtraan guru, peningkatan kualitas guru, hingga program peningkatan kompetensi guru sering dilakukan (Musfah, 2012). Upaya pemerintah untuk meningkatkan kualitas guru menjadi bagian penting dalam peningkatan sumber daya siswa (Sukarya, 2020).

Sebagaimana yang telah terjadi saat ini, kondisi pandemic telah mewajibkan guru untuk aktif dalam pembelajaran daring. Sehingga upaya-upaya dilakukan untuk melangsungkan proses pembelajaran. Saat ini gurulah yang mendapatkan perhatian lebih banyak diantara komponen-komponen sistem pendidikan (Indriyani, Saefulloh \& Riono, 2020). Besarnya perhatian terhadap guru antara lain dapat dilihat dari banyaknya kebijakan khusus seperti kenaikan tunjangan fungsional guru dan sertifikasi guru. Usaha-usaha untuk mempersiapkan guru menjadi profesional telah banyak dilakukan. Kenyataan menunjukkan bahwa tidak semua guru pemula memiliki kinerja yang baik dalam melaksanakan tugasnya (Berliani, 2017).

Berdasarkan kenyataan tersebut, kompleksnya tugas serta peran guru tersebut, perlu diadakan supervisi atau pembinaan terhadap guru secara terus menerus untuk meningkatkan kinerjanya. Kinerja guru perlu ditingkatkan agar usaha 
membimbing siswa untuk belajar dapat berkembang. Semakin meningkatnya kompetensi dan keterampilan guru dalam mengajar akan memberikan dampak yang baik dalam dunia pendidikan (Hasanah \& Kristiawan, 2019).

Pada masa pandemi guru memiliki peran fasilitator sempurna. Guru tidak dapat lagi memberikan ceramah semata, guru di tuntut untuk mahir dalam menggunakan fasilitas pendidikan jarak jauh. Selain tugas pokok guru adalah mengajar dan mendidik di sekolah, guru wajib menjadi mediasi dengan orang tua selama pembelajaran daring (Hayati, 2020; Chusna \& Utami, 2020; Indriyani, 2021). Selain itu, seorang guru harus mempersiapkan dan mengembangkan pengetahuan, sikap, dan keterampilan siswanya dalam menghadapi begitu cepat dan derasnya gelombang globalisasi.

Dengan diberlakukannya pembelajaran daring maka makin gagapnya seorang guru menghadapi situasi pembelajaran. Namun segala bentuk upaya dapat di lakukan untuk melangsungkan proses mengajar, dari penggunaan zoom, google team, google meeting hingga classroom. Penggunaan aplikasi pembelajaran dapat menjadi alternative pembelajaran daring. Berdasarkah temuan penelitian terdahulu tentang pembelajaran daring menggunakan WhatsApp, di peroleh bahwa penggunaan WhatsApps massenger cukup efektif untuk digunakan (Pustikayasa, 2019; Darmalaksana, 2020; Yensy, 2020).

Salah satu aplikasi dari WhatsApp Messenger yang bisa di gunakan untuk pembelajaran yaitu WAG yang dapat mengakomodir banyak anggota (siswa) dalam sebuah group belajar. Dengan memberlakukan pembelajaran daring ini maka perlu rasanya upaya peningkatan kemampuan guru dalam menggajar khusunya menggunakan WAG. Berdasarkan hal terebut, peneliti juga mengidentifikasi bahwa terdapat masalah-masalah yang muncul dalam penggunaan WAG sebagai berikut: (1) guru belum mahir menggunakan WAG dalam pembelajaran daring di masa pandemi Covid 19, dan (2) Sebagian besar guru belum mendapatkan pelatihan pengembangan keterampilan mengajar di masa pandemi covid 19.

Dalam hal ini, peneliti mencoba memberikan solusi untuk pemecahan masalah dengan meningkatkan keterampilan Guru dalam mengajar menggunakan media WAG serta memberikan pelatihan dan pembimbingan pada guru PNS dan Honorer di lingkungan SDN No. 121/IX Jerambah Bolong. Dari fokus permasalahan dan solusi, maka peneliti dapat merumuskan permasalahan penelitian ini menjadi "Apakah peningkatan keterampilan Guru dalam mengajar menggunakan media WAG di SDN No. 121/IX Jerambah Bolong tahun pelajaran 2020/2021 dapat diterapkan?"

\section{METODE PENELITIAN}

Penelitian ini merupakan penelitian tindakan sekolah (School Action Research), dimana peneliti menemukan guru-guru kesulitan menggunakan platform pembelajaran jarak jauh yaitu WAG. Metode ini dipilih karena penelitian dilakukan untuk memecahkan masalah guru selama mengajar di sekolah (Aas, Vennebo \& Halvorsen, 2020). Penelitian ini menggambarkan bagaimana suatu media pembelajaran diterapkan dan bagaimana hasil yang diinginkan dapat dicapai. Penelitian ini berlokasi di SDN No. 121/IX Jerambah Bolong yang beralamat di Jalan Lintas Talang Belido RT 26 Desa Mekar Jaya Kecamatan 
Sungai Gelam Kabupaten Muaro Jambi Provinsi Jambi. Adapun waktu penelitian dilaksanakan pada tahun pelajaran 2020/2021 selama kurang lebih 4 bulan dimulai 27 Juli sampai dengan 29 Oktober 2020.

Penelitian ini mengambil bentuk penelitian tindakan sekolah (PTS) yaitu peningkatan kinerja guru melalui kunjungan kelas dalam rangka mengimplementasikan standar proses, yang terdiri dari 3 siklus dan masingmasing siklus terdiri dari 4 tahap yaitu: (1) tahap perencanaan program tindakan, (2) pelaksanaan program tindakan, (3) pengamatan program, (4) refleksi. Untuk lebih jelas lihat di bawah ini:

Adapun alur dari penelitian ini sebagaimana bagan berikut.

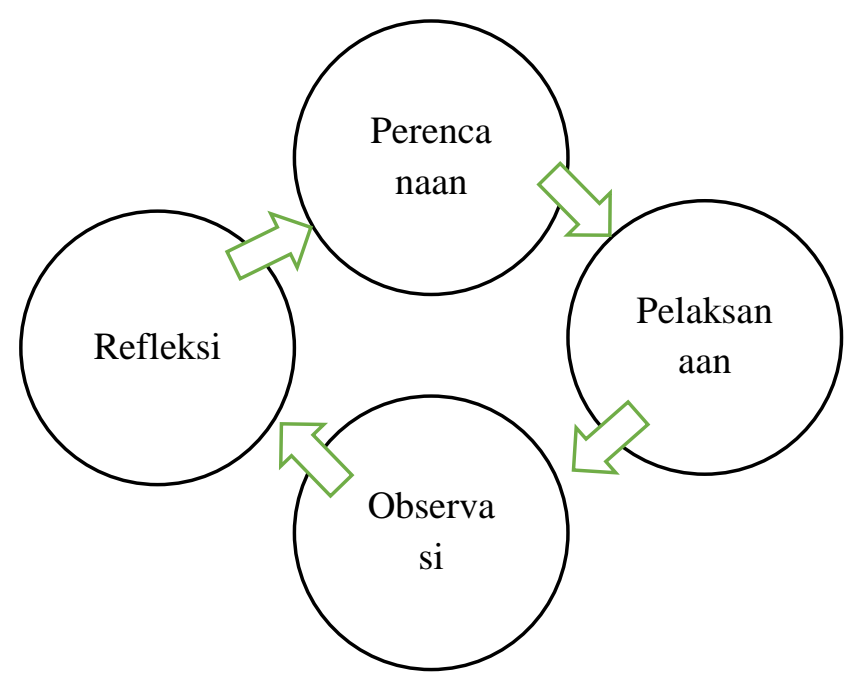

Bagan 1. Alur penelitian tindakan sekolah

Bagan di atas mengisaratkan rangka penelitian tindakan sekolah yang saling berkaitan dimulai dari perencanaan hingga refleksi. Keempat kegiatan tersebut saling terkait dan secara urut membentuk sebuah siklus. Penelitian Tindakan Sekolah merupakan penelitian yang bersiklus, artinya penelitian dilakukan secara berulang dan berkelanjutan sampai tujuan penelitian dapat tercapai.

Analisis data yang dilakukan dengan menggunakan metode deskriptif (Kemp, Hollowood \& Hort, 2018) dengan menggunakan teknik persentase untuk melihat peningkatan yang terjadi dari setiap siklus. Dengan metode ini peneliti berupaya menjelaskan data yang peneliti kumpulkan melalui komunikasi langsung atau wawancara, observasi/pengamatan, dan diskusi yang berupa persentase atau angka-angka.

\section{HASIL DAN PEMBAHASAN}

Dari hasil data yang didapatkan pada kondisi awal (pra siklus) terhadap 22 orang guru, peneliti memperoleh informasi bahwa semua guru (enam orang) 5 diantaranya sudah pernah melakukan penerapan pembelajaran di kelas yang berpartisipasi dan kreatif, 17 orang lainnya masih menerapkan model pembelajaran yang konvensional/ceramah, kebanyakan guru tidak tahu dan tidak paham menerapkan model pembelajaran/media pembelajaran cocok digunakan dimasa pandemi covid 19 yang melanda Indonesia. Hal ini di pengaruhi belum 
adanya pengetahuan guru tentang pembelajaran daring. Keterampilan guru dalam memilih media pembelajaran adalah keterampilan yang melengkapi seorang pendidik (Alwi, 2017).

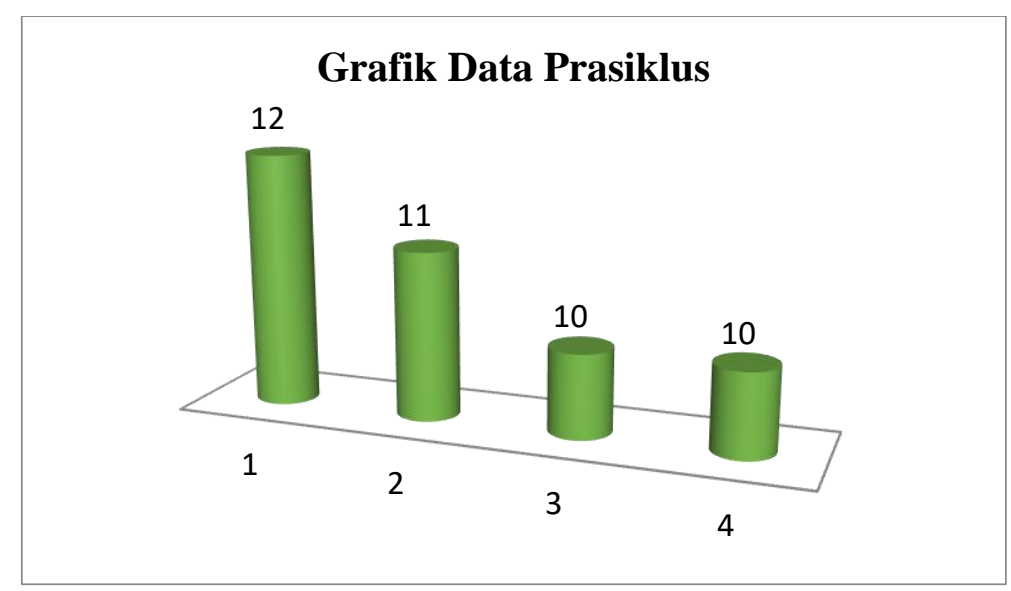

Gambar 1. Data Pra Siklus

Berdasarkan hasil observasi peneliti terhadap keterampilan guru dalam mengajar menggunakan media WAG yang dilakukan guru pada masa pandemi covid 19. Dari 22 sampel penelitian diperoleh hasil temuan bahwa hanya 12 orang guru yang membuat peraturan WAG pada siswanya. Selanjutnya, hanya 11 orang guru yang melakukan penjadwalan pembelajaran melalui WAG pada siswanya. Hanya 10 orang guru yang mengatur pengaturan Whatsapp pada siswanya. Serta, hanya 10 orang guru yang berkomunikasi rutin kepada kepala sekolah.

Secara rata-rata proses pembelajaran masih jauh dari yang diharapkan dengan capaian persetase Keterampilan Guru Dalam Mengajar Menggunakan Media WAG didapatkan 48,86\% dari semua indikator penilaian Keterampilan mengajar guru. Keterampilan guru dalam mengajar harus di tingkatkan dengan memberikan sebuah motivasi yang secara terus menerus (Kartini \& Kristiawan, 2019).

\section{Siklus I}

Penelitian ini dilakukan atas dasar permasalahan guru dalam menggunakan WAG yang belum maksimal. Maka peneliti memberikan solusi untuk melakukan pelatihan dan bimbingan. Setelah melakukan siklus I diperoleh temuan hasil. Hasil data yang didapatkan setelah dikalukan tindakan peningkatan keterampilan guru melalui pelatihan yang diupayakan untuk meningkatkan kemampuan guru dalam mengajar dengan menggunakan media WAG pada Siklus I didapatkan data terhadap 22 orang guru, diperleh data seperti pada Gambar 2.

Data yang peneliti peroleh bahwa 22 guru diantaranya sudah mencoba menggunakan media WAG dalam pembelajaran di masa pandemi covid 19 hal ini dapat dilihat dari diperoleh informasi dan data bahwa hanya 16 orang guru membuat peraturan WAG pada siswanya dari 22 orang guru, hanya 15 orang guru yang melakukan Penjadwalan pembelajaran melalui WAG pada siswanya dari 22 orang guru, hanya 12 orang guru yang Mengatur Pengaturan Whatsapp pada siswanya dari 22 orang guru, hanya 12 orang guru yang Komunikasi rutin kepala sekolah dengan guru dari 22 orang guru. 


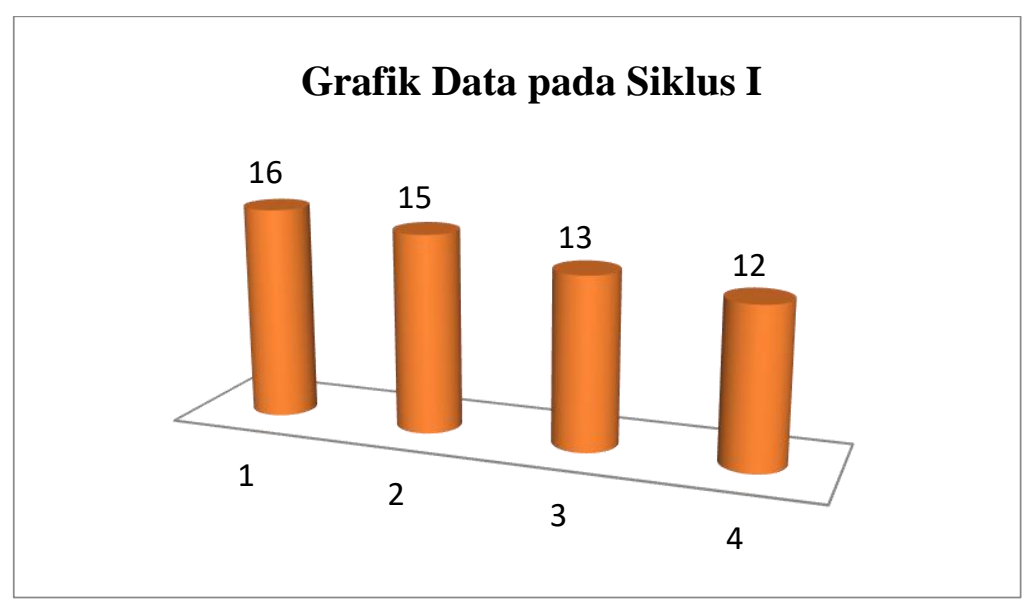

Gambar 2. Data Pada Siklus I

Secara rata-rata proses pembelajaran masih jauh dari yang diharapkan dengan capaian persetase keterampilan guru dalam mengajar menggunakan media WAG dimasa covid 19 denga hasil 63,64\% dari semua indikator penilaian keterampilan guru dalam mengajar menggunakan media WAG hal ini tentunya belum mencapai tujuan dari penelitian ini yang isyaratkan capaian persentase Indikator keterampilan guru dalam mengajar menggunakan media WAG pada angka $70 \%$. Penyebab belum maksimalnya keterampilan guru dalam menggunakan WAG pada siklus I adalah kurang aktifnya guru dalam mendiskusikan permasalahan teknis saat pembelajaran. Guru kelas bawah dan guru bidang studi yang membutuhkan perhitungan masih kesulitan dalam merangkum materi pembelajaran yang akan disamaikan menggunakan WhatsApp. Berdasarkan masukan supervisor atas temuan tersebut, maka peneliti merancang perbaikan pelatihan dan bimbingan teknis pada siklus II dengan menerapkan metode pelatihan kelompok yang memecahkan permasalahan masing-masing guru bidang studi. Penggunaan metode ini diharapkan akan meningkatkan keterampilan guru dalam pembelajaran menggunakan WAG pada siklus II. Oleh karena itu perlu dilakukan kembali Siklus yang ke II. Kurangnya peningkatan signifikan ini bisa di sebabkan berbagai factor. Factor external yang biasanya mempengaruhi lebih banyak dalam menghambat peningkatan keterampilan guru (Malinda, 2018).

\section{Siklus II}

Berdasarkan refleksi siklus pertama yang terindikasi bahwa permasalahan yang terjadi pada teknis pembelajaran tiap bidang studi, akhirnya peneliti merancang metode pelatihan dengan perbaikan pelatihan dan bimbingan teknis pada siklus II dengan menerapkan metode pelatihan kelompok yang memecahkan permasalahan masing-masing guru bidang studi. Dari hasil temuan siklus II, peneliti menemukan secara rata-rata nilai keseluruhan telah terjadi peningkatan telah terjadi peningkatan keterampilan guru dalam mengajar menggunakan media WAG di masa pandemi covid 19. Berikut data Penelitiannya digambarkan seperti pada Gambar 3. 


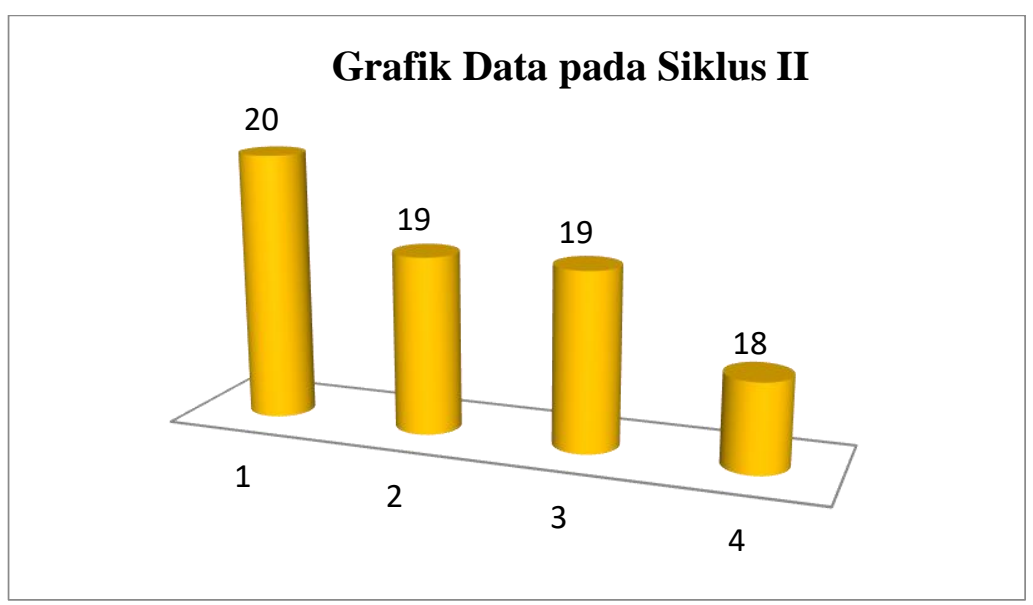

Gambar 3. Data Siklus II

Data yang peneliti peroleh dari setelah melakukan perbaikan tindakan pada siklus II, bahwa semua guru (enam orang) 6 diantaranya sudah mencoba Menggunakan Media WAG dengan baik dalam pembelajaran di masa pandemi covid 19 hal ini dapat dilihat dari diperoleh informasi dan data bahwa hanya 20 orang guru membuat peraturan WAG pada siswanya dari 22 orang guru, hanya 19 orang guru yang melakukan Penjadwalan pembelajaran melalui WAG pada siswanya dari 22 orang guru, hanya 19 orang guru yang Mengatur Pengaturan Whatsapp pada siswanya dari 22 orang guru, hanya 18 orang guru yang Komunikasi rutin kepala sekolah dengan guru dari 22 orang guru.

Secara rata-rata proses pembelajaran sudah melebihi dari yang diharapkan dengan capaian persetase keterampilan guru dalam mengajar menggunakan media WAG dimasa pandemi covid 19 yaitu 86,36\% dari semua aspek penilaian keterampilan dengan penerapan pendekatan saintifik. Hasil ini tentunta telah melebihi persentase indikator Keterampilan Guru Dalam Mengajar Menggunakan Media WAG pada angka $70 \%$ yang di syaratkan.

Pada siklus pertama merupakan awal upaya Peningkatan Keterampilan Guru Dalam Mengajar Menggunakan Media WAG di SDN No. 121/IX Jerambah Bolong Tahun Pelajaran 2020/2021, pada siklus 1 masih ditemukan beberapa guru masih belum dapat memahami bagaimana menggunakan media WAG dalam pembelajaran dimasa covid 19, khususnya pada indikator Penjadwalan pembelajaran melalui WAG, Mengatur Pengaturan Whatsapp dan Komunikasi rutin kepala sekolah dengan guru.

Data yang didapatkan bahwa persentase pencapai dari keseluruhan indikator Keterampilan Guru Dalam Mengajar Menggunakan Media WAG hanya berada pada angka 63,64\% dan ini sedikit lagi dari target yang diharapkan karena target yang ingin dicapai pada penerapan pembelajaran menggunakan media WAG ini adalah $70 \%$ guru telah memiliki keterampilan guru dalam mengajar menggunakan media WAG dimasa covid 19 pada pelajaran. Dikarenakan belum tercapainya tujuan itu maka diperlukan tindakan perbaikan (siklus II). 


\section{Aspek Keterampilan Mengajar Guru pada Pra Siklus Hingga Siklus II}

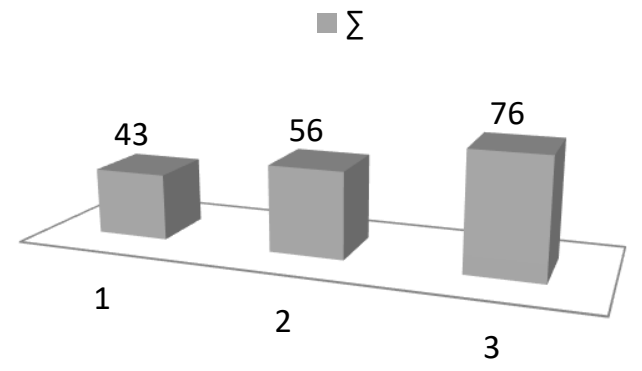

Gambar 4. Rata Pencapain Aspek Keterampilan Mengajar Guru

Pada siklus kedua, peneliti melakukan perbaikan dalam melakukan tindakan baik itu bimbingan dan arahan terhadap guru dalam menggunakan media WAG maka didapatkan hasil yang sangat baik. Dari 4 indikator keterampilan guru dalam mengajar menggunakan media WAG Guru telah mencapai hasil yang sangat baik dengan capai $86,36 \%$.

\section{Persentase Peningkatan Keterampilan Mengajar Guru dari Pra Siklus hingga Siklus II}

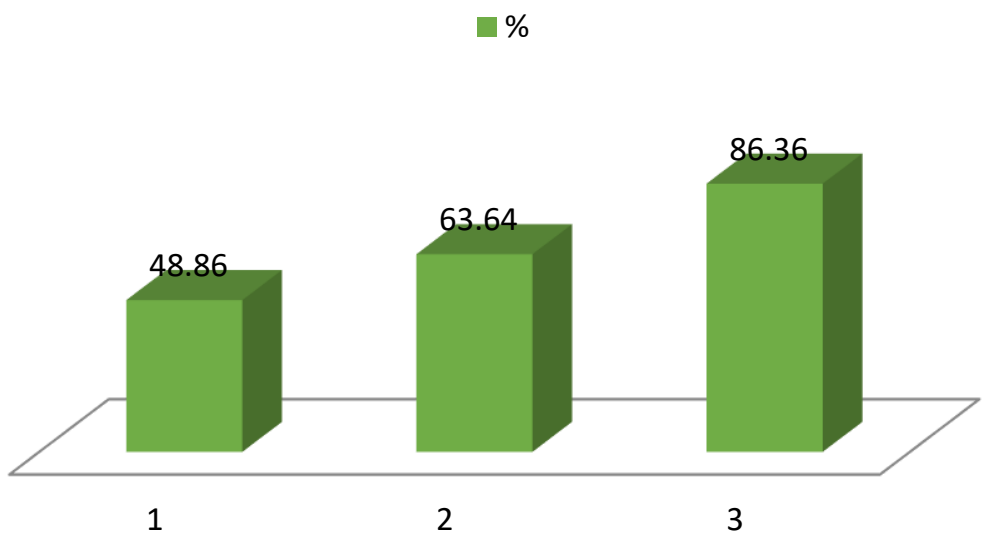

Gambar 5. Persentase Peningkatan Keterampilan Mengajar Guru

Hasil ini tentunya telah melebihi target pencapaian yang telah ditentukan pada angka $70 \%$, sehingga pemberian penerapan pendekatan saintifik ini berhasil menambah keterampilan guru dalam mengajar menggunakan media WAG.

Keterampilan guru dalam menggunakan media WAG berhasil. Keberhasilan ini terlihat dari dua siklus yang dilakukan oleh peneliti melalui pelatihan. Pelatihan tersebut didukung oleh keteguhan dan keuletan guru. Tanpa adanya motivasi dan keuletan guru dalam menginkatkan pasitasnya dalam pelatihan peneliti menilai tidak akan berhasil (Sahartian, 2018; Sudana, 2018). Dalam hal ini, kemampuan guru dan kesungguhan pelatih akan memberikan pengaruh positif dalam peningkatan keterampilan belajar di masa pandemi (Fadhila, 2017). 


\section{SIMPULAN}

Berdasarkan hasil Penelitian Tindakan Sekolah dapat disimpulkan bahwa; bimbingan berkelanjutan dapat meningkatkan keterampilan mengajar guru dalam mengajar menggunakan media WAG. Guru menunjukkan keseriusan dalam melakukan mengelola WAG untuk proses pembelajaran bersama siswa di SDN No. 121/IX Jerambah Bolong dari peneliti. Informasi ini peneliti peroleh dari hasil pengamatan pada saat mengadakan wawancara dan bimbingan kepada para guru. Hal itu dapat dibuktikan dari hasil observasi/pengamatan yang memperlihatkan bahwa terjadi peningkatan keterampilan guru dalam menggunakan WAG dari siklus ke siklus. Pada siklus I nilai rata-rata nilai Indikator Keterampilan Guru Dalam Mengajar Menggunakan Media WAG pada angka 63,64\% hal ini masih jauh dari yang diharapkan dengan pencapaian $70 \%$ sehingga perlu dilakukan Siklus II, pada siklus II pencapaian keterampilan guru mengajar dengan menggunakan media WAG pada angka $86,36 \%$ dan telah melbihi dari target yang diinginkan yaitu 70\%. Telah terbukti bahwa dengan bimbingan Menggunakan Media WAG pada guru dalam rangka peningkatan keterampilan mengajar di SDN No. 121/IX Jerambah Bolong telah berhasil. Sehingga, kegiatan ini dapat diadopsi untuk meningkatkan keterampilan guru dalam menggunakan WAG sebagai media belajar di masa pandemi.

\section{UCAPAN TERIMA KASIH}

Peneliti mengucapkan terimakasih kepada majelis guru SDN No. 121/IX jerambah bolong, Muaro Jambi, Jambi serta siswa dan siswi yang selalu memberikan semangat dan kesempatan dalam terselesaikannya penelitian ini.

\section{REFERENSI}

Aas, M., Vennebo, K. F., \& Halvorsen, K. A. (2020). Benchlearning-an action research program for transforming leadership and school practices. Educational action research, 28(2), 210-226. https://doi.org/10.1080/09650792.2019.1566084

Alwi, S. (2017). Problematika guru dalam pengembangan media pembelajaran. ITQAN: Jurnal Ilmu-Ilmu Kependidikan, 8(2), 145-167.

Berliani, T. (2017). Implementasi Supervisi oleh Kepala Sekolah dalam Meningkatkan Profesionalisme Guru. JMSP (Jurnal Manajemen dan Supervisi Pendidikan), 1(3), 218-226.

Chusna, P. A., \& Utami, A. D. M. (2020). Dampak pandemi COVID-19 terhadap peran orang tua dan guru dalam meningkatkan kualitas pembelajaran daring anak usia sekolah dasar. Premiere: Journal of Islamic Elementary Education, 2(1), 11-30. https://doi.org/10.51675/jp.v2i1.84

Darmalaksana, W. (2020). WhatsApp Kuliah Mobile. Fakultas Ushuluddin UIN Sunan Gunung Djati Bandung [PDF File]. Tersedia: http://digilib.uinsgd.ac.id/id/eprint/30354

Fadhila, R. (2017). Motivasi Kerja Guru di Sekolah Dasar Negeri Kecamatan V Koto Kampung Dalam Kabupaten Padang Pariaman (Doctoral dissertation, Universitas Negeri Padang). 
Hasanah, M. L., \& Kristiawan, M. (2019). Supervisi Akademik dan Bagaimana Kinerja Guru. Tadbir: Jurnal Studi Manajemen Pendidikan, 3(2), 97-112. http://dx.doi.org/10.29240/jsmp.v3i2.1159

Hayati, A. S. (2020). Peran Orang Tua dalam Meningkatkan Motivasi Belajar Anak Dengan Sistem Daring pada Masa Pandemi di Desa Depokrejo, Kebumen. Tasyri': Jurnal Tarbiyah-Syari'ah Islamiyah, 27(2), 23-32.

Indriyani, A., Saefulloh, M., \& Riono, S. B. (2020). Pengaruh Diklat Kependidikan dan Kesejahteraan Guru terhadap Kualitas Guru di Sekolah Dasar Negeri di Kecamatan Jamblang Kabupaten Cirebon. Syntax Idea, 2(7), 176-193. https://doi.org/10.36418/syntax-idea.v2i7.441

Indriyani, F. (2021). Peran Orang Tua Dalam Pelaksanaan Pembelajaran Daring Pada Siswa Sekolah Dasar Di Pulau Rona Kecamatan Bangkinang. Jurnal Pendidikan dan Konseling (JPDK), 3(1), 90-96. https://doi.org/10.31004/jpdk.v3i1.1434

Kartini, D., \& Kristiawan, M. (2019). Pengaruh tunjangan profesi dan motivasi kerja terhadap kinerja guru. Kelola: Jurnal Manajemen Pendidikan, 6(1), 2533. https://doi.org/10.24246/j.jk.2019.v6.i1.p25-33

Kemp, S. E., Ng, M., Hollowood, T., \& Hort, J. (2018). Introduction to descriptive analysis. In Kemp, S. E., Hort, J., \& Hollowood, T. (Eds.), Descriptive analysis in sensory evaluation. Hoboken, NJ: John Wiley \& Sons Ltd.

Malinda, T. D. (2018). Hambatan-hambatan guru dalam pengelolaan kelas di kelas III SDN Sawojajar 3 Kecamatan Kedungkandang Kota Malang (Doctoral dissertation, Universitas Negeri Malang).

Musfah, J. (2012). Peningkatan kompetensi guru: Melalui pelatihan dan sumber belajar teori dan praktik. Jakarta: Kencana.

Pustikayasa, I. M. (2019). Grup WhatsApp Sebagai Media Pembelajaran. Widya Genitri: Jurnal Ilmiah Pendidikan, Agama Dan Kebudayaan Hindu, 10(2), 5362. https://doi.org/10.36417/widyagenitri.v10i2.281

Sahartian, S. (2018). Pemahaman Guru Pendidikan Agama Kristen Tentang II Timotius 3: 10 Terhadap Peningkatan Kecerdasan Spiritual Anak Didik. Fidei: Jurnal Teologi Sistematika dan Praktika, 1(2), 146-172. https://doi.org/10.34081/fidei.v1i2.15

Sudana, D. N. (2018). Pelatihan dan Pengembangan Perangkat Pembelajaran Berdasarkan Permendikbud Nomor 22 Tahun 2016 pada Guru-Guru di Gugus V Kediri, Kecamatan Kediri Kabupaten. International Journal of Community Service Learning, 2(1), 22-27. http://dx.doi.org/10.23887/ijcsl.v2i1.13680

Sukarya, E. (2020). Upaya Meningkatkan Kompetensi Guru Dalam Menyusun Rencana Pelaksanaan Pembelajaran Kurikulum 2013 Melalui Pendampingan. Jurnal Educatio FKIP UNMA, 6(2), 611-617. https://doi.org/10.31949/educatio.v6i2.620

Yensy, N. A. (2020). Efektifitas Pembelajaran Statistika Matematika melalui Media Whatsapp Group Ditinjau dari Hasil Belajar Mahasiswa (Masa Pandemik Covid 19). Jurnal Pendidikan Matematika Raflesia, 5(2), 65-74. https://doi.org/10.33449/jpmr.v5i2.11410 